\section{CROWS AND OWLS}

On 17 April 1987 I was driving on a country road in the Rock Point district near Lucky Lake, Saskatchewan. A flock of crows was causing a commotion in a large poplar located on an abandoned farmstead. I drove into the yard to investigate. When I walked across the yard and through a small shelter belt a Great Horned Owl flew down from a poplar tree and passed very close (too close) to my uncovered head causing a few hasty steps in retreat. A nest containing three young owls was seen approximately $2.2 \mathrm{~m}$ above ground on a rotted poplar stump. I stayed about 30 minutes, and although the adult owls gave an occasional hoo hoo, and snapped their beaks, they did not seem to mind my presence nearly as much as that of the crows, who continually harassed them. I strongly suspect the crows would have killed the young owls had the parents not been close by.

On 20 April the crows were still making life miserable for the owls. Owl pellets found in the area indicated the owls were hunting successfully at night. - Myron Barton, R.R. 5, Site 16, Box 51, Prince Albert, Saskatchewan. S6V 5R3

\section{MORE HUMMINGBIRD-- SAPSUCKER INTERACTIONS}

We were very interested in the article Ruby-throated Hummingbird associating with a foraging Hairy Woodpecker (Dec 86 Blue Jay) as the same thing has been happening in our farm yard for the past three years.

Our bird was a Yellow-bellied Sapsucker and one or two Ruby-throated Hummers would leave the feeder when this bird came to the Maple or Dropmore Elm trees close by; they would wait patiently on the branch until it decided to go to another tree, then they would feed on the sap drips made by the sapsucker.

We covered the markings made by the sapsucker with cloth and we often observed the hummingbirds feeding on the cloth as it became damp with the sap.

After we discouraged the sapsucker, the hummingbirds returned to the feeder but if a sapsucker should appear they immediately followed it to whatever tree it went.

This we felt was a usual occurence after having observed it so many times in the years we have been feeding hummingbirds. - Mildred and Jim Spear, Box 914, Russell, Manitoba. R0J 1W0 